University of Vermont

UVM ScholarWorks

2018

\title{
Quantifying stream phosphorus dynamics and total suspended sediment export in forested watersheds in Vermont
}

Sophia C. Ryan

The University of Vermont

Beverley Wemple

The University of Vermont

Donald Ross

The University of Vermont

Follow this and additional works at: https://scholarworks.uvm.edu/hcoltheses

\section{Recommended Citation}

Ryan, Sophia C.; Wemple, Beverley; and Ross, Donald, "Quantifying stream phosphorus dynamics and total suspended sediment export in forested watersheds in Vermont" (2018). UVM Honors College Senior Theses. 256.

https://scholarworks.uvm.edu/hcoltheses/256

This Honors College Thesis is brought to you for free and open access by the Undergraduate Theses at UVM ScholarWorks. It has been accepted for inclusion in UVM Honors College Senior Theses by an authorized administrator of UVM ScholarWorks. For more information, please contact scholarworks@uvm.edu. 


\title{
Quantifying stream phosphorus dynamics and total suspended sediment export in forested watersheds in Vermont
}

\author{
A thesis in partial fulfillment of the \\ Bachelor of Arts degree with Honors in Geography \\ Submitted by \\ Sophia Ryan \\ April 30 ${ }^{\text {th }}, 2018$ \\ Examining Committee: \\ Dr. Beverley Wemple, Associate Professor, Geography \\ Dr. Donald Ross, Research Professor, Plant and Soil Science \\ Dr. Julia Perdrial, Assistant Professor, Geology \\ University of Vermont
}




\section{Acknowledgements}

\section{Project funded by USGS}

Special thanks to: Joel Tilley from University of Vermont's Agricultural testing Lab; Liza Lemieux and Shayla Triantafillou for lab and field assistance; Alan Howard for help with regressions; and Wilton Burns for help with R.

Thank you to my thesis advisors: Beverley Wemple and Donald Ross and thank you to my thesis defense committee: Beverley Wemple, Donald Ross and Julia Perdrial.

Thank you to my friends and family for their guidance and support. 


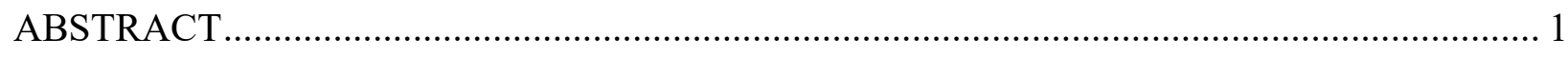

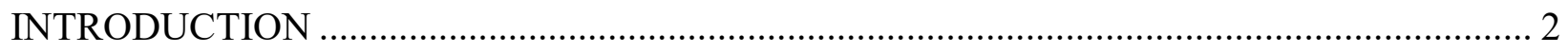

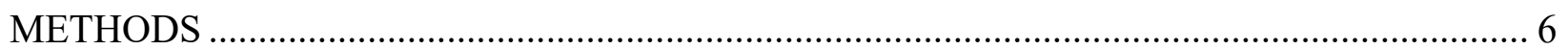

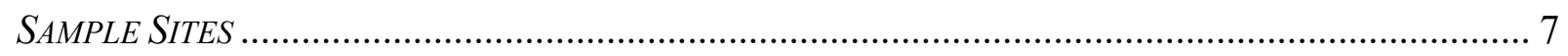

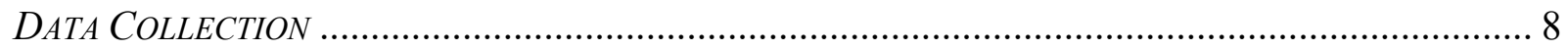

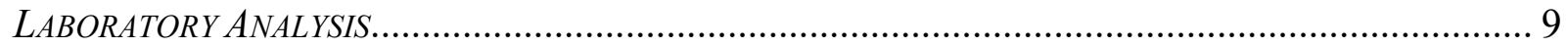

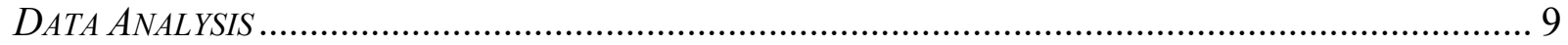

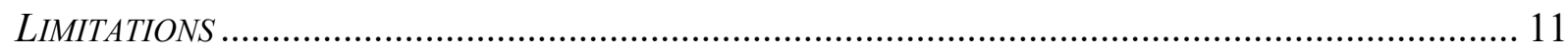

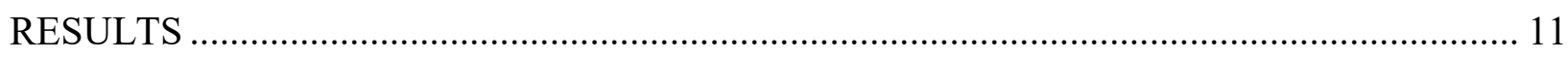

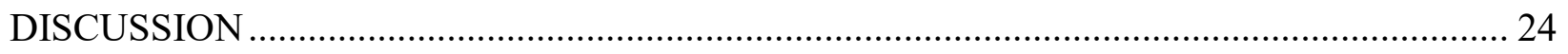

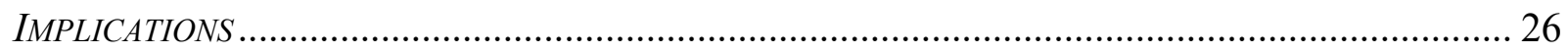

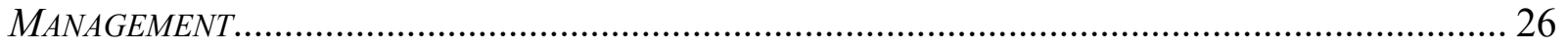

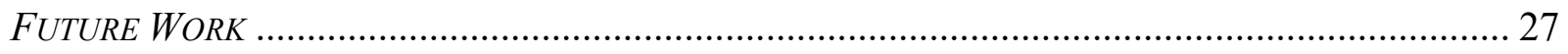

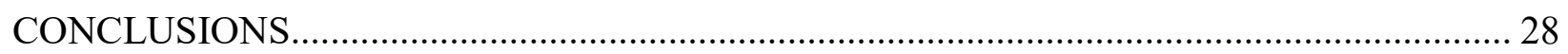

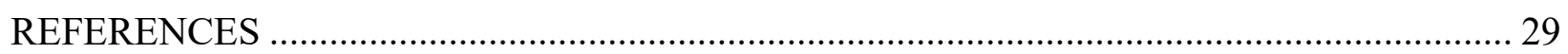




\begin{abstract}
Globally the quantity of reactive phosphorus (P) in soils, streams and groundwater has greatly increased throughout the 20 th and early 21 st centuries. This phenomenon is problematic in Vermont, evidenced by the repeated cyanobacteria blooms in shallow bays in Lake Champlain. While many studies have focused on P dynamics in agricultural watersheds, there is limited information on $\mathrm{P}$ dynamics in forested watersheds. Current remediation plans under the Lake Champlain total maximum daily loads (TMDL) call for substantial reductions in P loadings from forested areas of the basin. However, the lack of information and knowledge regarding forest $\mathrm{P}$ dynamics limits management and remediation plans. This study was conducted in three small forested watersheds, ranging in size from 2.5 to 8.3 square kilometers that have been managed under varying practices, including logging and maple sugaring. All three watersheds drain into Missisquoi Bay, a shallow bay in Lake Champlain that consistently has seasonal algal blooms. Streams in the forested watersheds were instrumented with turbidity sensors and pressure transducers to measure stage. A rating curve was developed during field visits to relate stage to discharge. Water samples were collected from May through November 2017 using ISCO Automated Samplers. A total of twenty storm events were captured, along with periodic baseflow sampling, and these data were used to characterize P concentrations and calculate seasonal P loadings. Results indicate that there is a strong positive relationship between turbidity, total suspended sediment and total phosphorus concentrations ( $\mathrm{R}^{2}$ ranging from 0.64 to 0.83 ). The results of this project provide insight into transport of $\mathrm{P}$ and total suspended sediment within forested catchments of Lake Champlain tributaries. In particular, the research shows that fluxes in total phosphorus are linked to fluxes in total suspended sediment and that the overall monthly totals of $\mathrm{P}$ being exported from forested catchments are low, relative to urban, suburban and agricultural areas.
\end{abstract}




\section{Introduction}

At a global scale water security and aquatic ecosystms are increasingly at risk of ongoing longterm degradation (Maybeck \& Helmer, 1989; Vorosmarty, 2010). Some of the variables at play in water quality are attributed to natural factors, including climate and vegetation (Meybeck \& Helmer, 1989). However, many of the problems that are felt at both local and global scales can geneally be credited to human influence (Vorosmarty, 2010).

Over the past few centuries sediment in waterways has risen steadily (Walling, 1999). This increase can be largely attributed to an increase in urban and agricultural landscapes, which export more sediment than less disturbed landscapes (Allan et al., 1997; Walsh et al., 2005). Therefore, this exacerbates sedimentation and contamination on local and global scales (Allan et al., 1997; Walsh et al., 2005). This increase in sediment has resulted in an excess of nutrients in both freshwater and marine ecosystems, contributing to deteriorating ecosystems and public health concerns (WHO, 1990; Pilotto et al., 1997; Dolah, 2000; Xu et al., 2001).

The EPA lists sediment as the most common contaminant to waterways in the United States (EPA, 2016c). This is problematic due to the negative effects that increased sediment have on aquatic ecosystems and water quality (EPA, 2016c). These negative effects include habitat destruction of myriad marine and freshwater species; contamination of drinking water sources, and an increase in nutrients which can cause toxic algal blooms (USGS, 2016). Anthropogenic alterations to landscapes, such as agricultural practices, landscape development, and deforestation, account for 70 percent of the sediment released into waterways annually. The other 30 percent of sediment is introduced into waterways through natural erosion of bedrock, hillslopes and streambanks (EPA, 2016c).

Landscape management has proven to be vital in reducing runoff and sediment release into waterways (Allan et al., 1997). However, there is a lag in the response rate of a watershed or aquatic system to these changes, therefore making it difficult to immediately see the effect of landscape change and remediation (Walling, 1983 \& Walling, 1999). An additional layer of difficulty in executing effective land and resource management plans is determining the source 
of sediment (Collins \& Walling, 2004). Sediment sources in forested landscapes include streambank and bedrock erosion, natural disturbances to the landscape, and anthropogenic disturbances such as dirt roads and logging (EPA, 2016b). Many of these sources can be difficult to identify and effectively address. General management techniques include stabilizing banks by introducing vegetation, implementing best management practices (BMPs) in agricultural and forested landscapes and redesigning storm water systems, to name a few (Walsh et al., 2005; Yuan et al., 2009; General Assembly of the State of Vermont, 2015).

Phosphorus (P) is a naturally occurring element that is vital for biological processes (Filippelli, 2008). Despite $P$ acting as a limiting reagent for many metabolic and photosynthetic processes in marine environments, there is an increasing issue of $\mathrm{P}$ loading in aquatic environments (Filippelli, 2008). Phosphorus is released naturally through the weathering of different sedimentary, metamorphic and igneous rocks, particularly from the mineral apatite (Filippelli, 2008). However, natural sources of $P$ only make up $0.09 \%$ wt of the earth's crust, contributing to its role as a limiting nutrient (Filippelli, 2008).

Phosphorus has been introduced anthropogenically to maintain and increase agricultural yields, leading to the current issue of $\mathrm{P}$ loading in waterways. While non-point source $\mathrm{P}$ is introduced into waterways through a variety of means, including weathering, and sediment dynamics such as bank erosion (Mulholland, 1992; Abrams \& Jarrell, 1995; Young \& Ross, 2001; Young \& Ross, 2012; Grundtner et al., 2014), the largest contributor of $P$ at a global scale is agricultural practices that involve adding $\mathrm{P}$ in the form of fertilizer and subsequent erosion of soil from farmland (Johnes, 1995; Bennett et al., 2001; Filippelli, 2008; Ghebremichael \& Watzin, 2011; Kronvang et al., 2012; Delmas et al., 2015; Alvarez et al., 2017; Gu et al., 2017).

Phosphorus moves through both soil and water cycles, and accumulates slowly, indicating the quantities of $\mathrm{P}$ in a certain area may not show their effects immediately after they are released into the system (Bennet et al., 2001). Given the redistribution in global P concentrations, P is accumulating in both terrestrial upland soils and marine sediments (Bennet et al., 2001). This suggests that over time as upland soils erode and are transported through streams to larger bodies 
of water, the quantity of phosphorus in marine environments will increase exponentially (Bennet et al., 2001).

Given that sediment is the main source of $\mathrm{P}$ to surface waters in forested areas, it is crucial to better understand sediment sources and transport in terrestrial environments in order to execute effective land management plans. Many different factors can affect the potential for soils to transport nutrients and contaminants into waterways. For example, some soils have a higher capacity to store nutrients due to sorbing properties (Gaddis \& Voinov, 2009). Clay-rich soils in particular have the capacity to store high quantities of $\mathrm{P}$, while sandy soils tend to store less $\mathrm{P}$ and therefore typically release less (Young \& Ross, 2012). Another caveat in attempting to understand natural, non-point sources of $\mathrm{P}$, is that $\mathrm{P}$ concentrations can change greatly over a few kilometers depending on weathering, parent material and topsoil composition (Delmas, 2015; Augusto, 2017).

Numerous studies conducted in small $\left(<10 \mathrm{~km}^{2}\right)$ forested watersheds, particularly in the western U.S., have attempted to quantify sediment yields from forest lands (Harr, 1977; Bilby, 1985; Anderson \& Potts, 1987; Luce \& Black, 1999; Gomi et al., 2005). Sources of sediment production in forested watersheds include landslides on steep hillslopes, scouring of channel beds and banks, and saturation of riparian zones (Beschta, 1979; Jackson \& Beschta, 1982; Kurashige, 1994; Rivenbark \& Jackson, 2004). Management of forested watersheds, including road construction and logging, have been shown to greatly amplify rates of sediment production and yield (Reid \& Dunne, 1984; Christie \& Fletcher, 1999; Kreutzweiser \& Capell, 2001; Luce \& Wemple, 2001; Wemple et al., 2001).

Fewer studies have focused on documenting phosphorus yields from forested watersheds. Intensive site level investigations in Oregon (Kelly et al., 1999) and New Hampshire (Meyer and Likens, 1979) aimed to understand factors at play regarding P concentrations. Kelley et al. (1999) found that in addition to sediment, groundwater seepage into waterways also has the potential to increase $\mathrm{P}$ concentrations, specifically during summer months. Meyer and Likens (1979) found that fine particulate matter was the greatest contributor of phosphorus in streams, but did not find any seasonal variability in phosphorus concentrations. In a synthesis of data from 
more than 300 forested streams in the U.S., Binkley et al. (2004) found that P concentrations tended to be lower in forested areas than other land uses and that forest harvesting had little effect on P export. A study conducted in the boreal plain of Alberta found P concentrations to be significantly lower in forested areas than in agricultural areas (Cooke \& Prepas, 1998). Ostrofsky et al. (2018) also found that forested areas export significantly less P than agricultural areas. This study found that streams draining forested areas exported 3.1 times less apatite $\mathrm{P}$ than streams draining from agricultural areas, and that forested streams exported 3.8 times less sediment than agricultural ones (Ostrofsky et al., 2018).

Since 1905 studies regarding nutrient loading and pollution have been conducted in Lake Champlain and its tributaries (Leighton, 1905). In the 1970's the research shifted to primarily looking at the negative side-effects of nutrient loading throughout the Lake Champlain Basin (Smeltzer et al., 1989). Multiple studies were conducted with a primary focus on non-point source agricultural contribution of phosphorus and nitrogen loadings into local waterways and ultimately Lake Champlain (Smeltzer, 1994; Meals, 1996). In 1985 the Army Corps of Engineers released a report which recommended reducing the amount of $\mathrm{P}$ entering waterways from both point source and non-point source contributors given levels of eutrophication in Lake Champlain (Lee et al., 1985). Throughout Vermont studies have been conducted regarding P dynamics in agricultural watersheds (Young \& Ross, 2001; Gaddis \& Voinov, 2009; Ghebremichael \& Watzin, 2010; Joung et al., 2017), but few have focused on phosphorus dynamics in forested watersheds.

In 2002 the EPA established a list of total maximum daily loads (TMDLs) for different nutrients in Lake Champlain, focusing primarily on P (EPA 2016a). These TMDLs were re-evaluated in 2015 based on Vermont's Clean Water Act Section 303(d), and new standards were implemented, resulting in a need for $\mathrm{P}$ export reduction plans for all watersheds that drain into Lake Champlain (Vermont, G. A., 2015). Missisquoi Bay accounts for almost 25\% of the total P inputs into Lake Champlain (EPA, 2016a), with agricultural and forested landscapes contributing 88 percent of phosphorus into the bay (EPA, 2016a). The EPA report calls for a 50 percent reduction of $\mathrm{P}$ in forested areas and a 68.5 percent reduction in streambank erosion within the Missisquoi watershed (Table 1). However, there has been little quantitative research conducted 
on $\mathrm{P}$ and sediment dynamics within forested areas in Vermont, making it difficult to establish and implement effective remediation plans to the degree that is necessary.

This thesis project was designed to address this research need, by conducting high frequency sampling of suspended sediment and P from three small forested streams within the Missisquoi watershed, while continuously monitoring runoff dynamics. In particular, the project aimed to examine storm and baseflow variability in sediment and $\mathrm{P}$ concentrations and to estimate monthly loads where sufficient data were available.

Table 1. Percent reductions needed to meet TMDL allocations for Vermont Segments of Lake Champlain. The five columns on the right outline reductions mandated for specific types of land use and, in the case of the last column, a specific source of P based on landuse (Table 8 of EPA, 2016a).

\begin{tabular}{|c|c|c|c|c|c|c|c|c|}
\hline Lake Segment & $\begin{array}{c}\text { Total } \\
\text { Overall } \\
\end{array}$ & Wastewater $^{1}$ & CSO & $\begin{array}{c}\text { Developed } \\
\text { Land }^{2}\end{array}$ & $\begin{array}{c}\text { Agricultural } \\
\text { Production } \\
\text { Areas }\end{array}$ & Forest & Streams & $\begin{array}{c}\text { Agricultural } \\
\text { Nonpoint }\end{array}$ \\
\hline 01. South Lake B & $41.4 \%$ & $0.0 \%$ & & $21.1 \%$ & $80.0 \%$ & $40.0 \%$ & $46.7 \%$ & $62.9 \%$ \\
\hline 02. South Lake A & $55.5 \%$ & $0.0 \%$ & & $18.1 \%$ & $80.0 \%$ & $5.0 \%$ & & $62.9 \%$ \\
\hline 03. Port Henry & $55.4 \%$ & & & $7.6 \%$ & $80.0 \%$ & $5.0 \%$ & & $62.9 \%$ \\
\hline 04. Otter Creek & $23.6 \%$ & $0.0 \%$ & & $15.0 \%$ & $80.0 \%$ & $5.0 \%$ & $40.1 \%$ & $46.9 \%$ \\
\hline 05. Main Lake & $20.5 \%$ & $61.1 \%$ & & $20.2 \%$ & $80.0 \%$ & $5.0 \%$ & $28.9 \%$ & $46.9 \%$ \\
\hline 06. Shelburne Bay & $11.6 \%$ & $64.1 \%$ & & $20.2 \%$ & $80.0 \%$ & $5.0 \%$ & $55.0 \%$ & $20.0 \%$ \\
\hline 07. Burlington Bay & $31.2 \%$ & $66.7 \%$ & $11.8 \%$ & $24.2 \%$ & $0.0 \%$ & $0.0 \%$ & & $0.0 \%$ \\
\hline 09. Malletts Bay & $17.6 \%$ & $0.2 \%$ & & $20.5 \%$ & $80.0 \%$ & $5.0 \%$ & $44.9 \%$ & $28.6 \%$ \\
\hline 10. Northeast Arm & $12.5 \%$ & & & $7.2 \%$ & $80.0 \%$ & $5.0 \%$ & & $20.0 \%$ \\
\hline 11. St. Albans Bay & $24.5 \%$ & $59.4 \%$ & & $21.7 \%$ & $80.0 \%$ & $5.0 \%$ & $55.0 \%$ & $34.5 \%$ \\
\hline 12. Missisquoi Bay & $64.3 \%$ & $51.9 \%$ & & $34.2 \%$ & $80.0 \%$ & $50.0 \%$ & $68.5 \%$ & $82.8 \%$ \\
\hline 13. Isle La Motte & $11.7 \%$ & $0.0 \%$ & & $8.9 \%$ & $80.0 \%$ & $5.0 \%$ & & $20.0 \%$ \\
\hline TOTAL & $33.7 \%$ & $42.1 \%$ & $11.8 \%$ & $20.9 \%$ & $80.0 \%$ & $18.7 \%$ & $45.4 \%$ & $53.6 \%$ \\
\hline
\end{tabular}

\section{Methods}

The study was conducted in three forested sub-watersheds in the Missisquoi River basin (Figure 1). The watersheds are small, ranging from 2.3 to 8.5 square kilometers, and are each managed differently. Ross Brook's watershed incorporates maple sugaring upstream, Kings Hill Brook's 
watershed is mainly managed for maple sugaring and logging, and the Richford stream watershed is also managed for logging. These three watersheds represent much of the diversity of forest land use and forest land management in Vermont, providing an applicable understanding of phosphorus dynamics amongst forest land use.
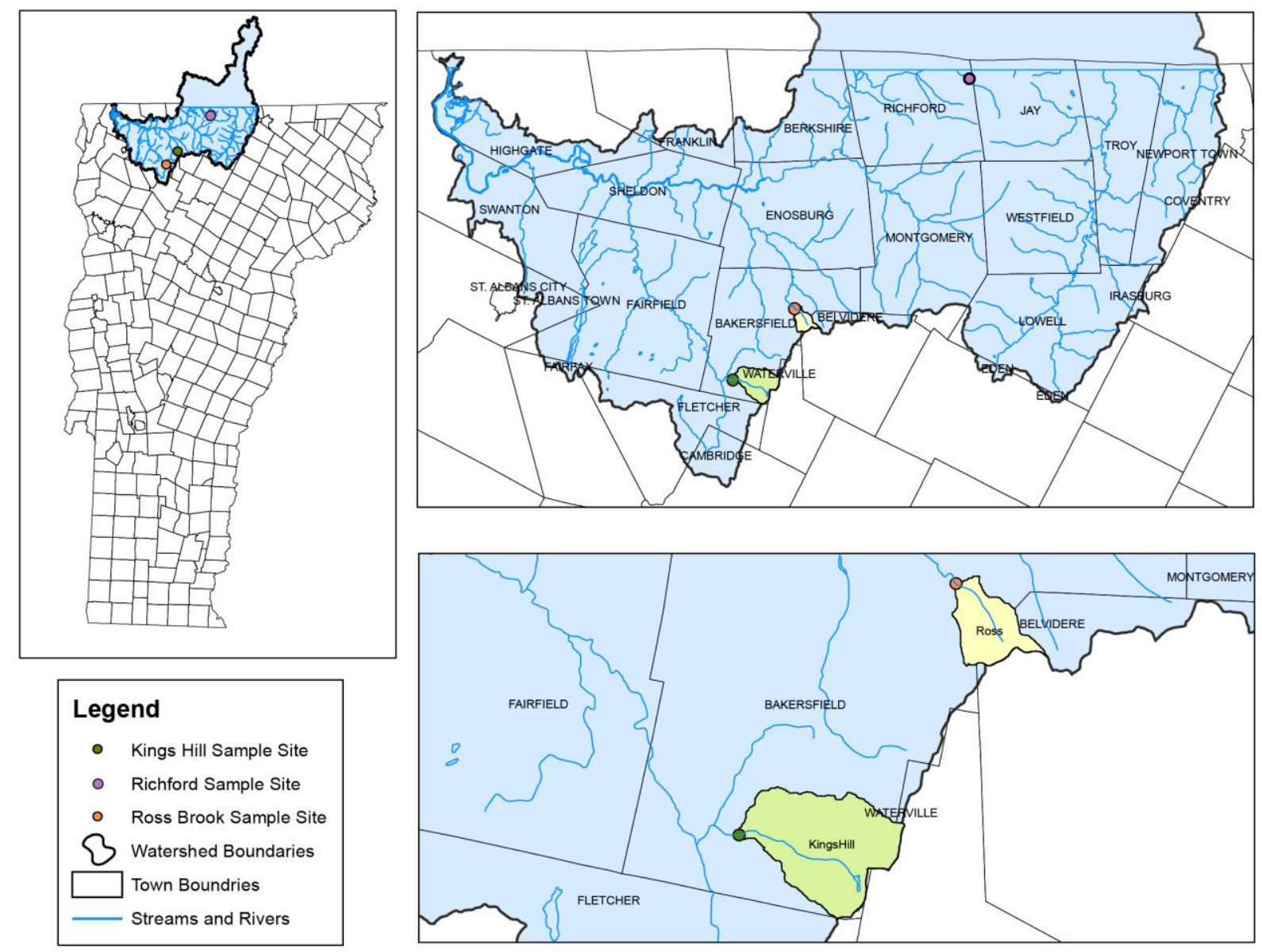

Figure 1. Sample sites located within the context of Vermont and the Missisquoi Basin. Ross Brook is in yellow and Kings Hill Brook is in green. The Richford stream site is noted in purple in the Vermont and Missisquoi maps.

\section{Sample Sites}

All three streams are located in forested watersheds. Ross Brook is located in Bakersfield, Vermont and is 2.9 square kilometers in size. Ross Brook is covered by forests with some interspersed pasture near the sample site and managed for maple sugar production upstream. Instrumentation was deployed for this site on May $17^{\text {th }}, 2017$ and removed on November $9^{\text {th }}$, 2017. 
Kings Hill Brook is also located in Bakersfield, Vermont and is 8.5 square kilometers in size, and fully forested. The watershed is managed by private landowners for timber production. A small sugarbush is located immediately south of the stream gauging station in the watershed with a gravel road running upslope of the stream. Instrumentation was deployed for this project on May $12^{\text {th }}, 2017$ and removed on November $9^{\text {th }}, 2017$.

The third stream does not have a name and is located off of Route 105 in Richford, Vermont. This watershed is 2.3 square kilometers in size and has undergone logging in the past 4 years and was chosen for this recent history of logging activity. Instrumentation was deployed to this stream for the first time on June $30^{\text {th }}, 2017$ and began collecting samples on August $16^{\text {th }}, 2017$ due to mechanical errors. Instrumentation was removed on November $9^{\text {th }}, 2017$.

\section{Data Collection}

Samples were collected through the use of a Teledyne ISCO 6712 automated sampler. The ISCO samplers were equipped with a pressure transducer to collect water level (stage) data and a Forestry Technology Services FTS-DTS12 digital turbidity sensor. These sensors, along with the ISCO sampler tubing were secured to rebar positioned in pools along a low gradient river reach in each watershed.

ISCO samplers were programmed to record water level and turbidity at 5 minute intervals throughout the sampling period. Water sample collection was programmed using a set point to trigger collection as water level rose during storm events. The set point changed with each field visit and storm event to accommodate changing baseflow water levels over the study period. When the water level reached the set point, samples were automatically collected every 30 minutes for the first eight samples and every hour for the following fourteen. The program was also set to collect two bottles if the turbidity exceeded a pre-determined set point (>1000 NTU).

In order to supplement the samples collected by the ISCO sampler, baseflow grab samples were collected each time the field sites were visited. These samples provided results about water chemistry at base flow. All water samples were stored in air-tight bottles in a cold room until sample processing. During the study period, a total of 392 samples were analyzed for TP and 
TSS (for most storm events every third sample was analyzed unless a lot of sediment was present). Of these, 17 were analyzed for SRP within 12 hours of sample collection.

In addition to the data collected through the ISCO, discharge measurements were also taken. Discharge was determined by measuring the width and depth of the stream sections along a cross section located at the gauging station. Velocity measurements for each section were taken using a Marsh-McBirney Flo-Mate 2000 Portable Water Flow Meter. Measurements were recorded manually and used to make discharge calculations. Discharge and stage were then used to produce rating curves using regression modeling tools in the SPSS statistical software package.

\section{Laboratory Analysis}

Both baseflow and precipitation event samples were analyzed to determine total phosphorus concentrations using a persulfate digestion on a Lachat QuikChem AE flow injection autoanalyzer. Grab samples from periods of baseflow and during storm events were analyzed for soluble reactive phosphorus (SRP) also using the Lachat QuikChem AE flow injection autoanalyzer. Water samples were filtered with a 0.45 micron filter before analysis on the Lachat. The Lachat automated colorimeter uses the Murphy-Riley molybdate blue method to measure accurate total phosphorus (TP) and soluble reactive phosphorus (SRP) concentrations. The detection limit for these samples was calculated using EPA guidelines for detection limits (EPA, 2016d). The calculated detection limit for this set of samples is $5 \mu \mathrm{g} / \mathrm{L}$.

Total suspended sediment (TSS) was determined by filtration and oven drying. Samples were filtrated through 0.45 micron filters and dried in the oven for an hour at $105^{\circ} \mathrm{C}$ (American Public Health Association, 1998). Sediment weight and volume of water were then used to calculate TSS in mg/L. All water samples were analyzed and stored at the University of Vermont Agricultural and Environmental Testing Lab in Jeffords Hall.

\section{Data Analysis}


Data visualization and plotting were accomplished using a combination of Excel graphical tools and scripting in the R programming language. Lab results for TSS and TP were analyzed for correlations with measured variables (TSS and TP to discharge and turbidity) and fit with regression models using SPSS (Figure 7). The strongest regressions, determined from highest model $\mathrm{R}^{2}$ values, were then used to predict TSS and TP concentrations for every five minutes throughout the sampling period. To incorporate an estimate of uncertainty in load estimation, 95\% confidence intervals on predicted TSS and TP calculations were generated for each 5 minute time-step over the monitoring period. These confidence intervals, along with predicted mean TSS and TP from the regression models, were used to generate 5-minute flux estimates by multiplying predicted concentrations by water flux volume ( 5 minute instantaneous discharge rate pro-rated over the 5 minute time-step). These loads were summed in order to predict total monthly loads of TP and TSS (Figure 8).

Sample sites were compared to a SWAT model designed to predict annual P export throughout the greater Missisquoi watershed based off land use, soil management, topography and agricultural management (Figure 9) (Winchell et al., 2015). Sample sites were overlaid on SWAT model results to see predictions and variability within the Ross Brook and Kings Hill Brook watersheds.

Data from long-term monitoring stations were acquired to help contextualize the study period. Precipitation data for the period January 1, 1981 to December 31, 2010 were acquired from [https://www.ncdc.noaa.gov/cdo-web/datasets/NORMAL_MLY/stations/GHCND:USC00437032/detail] a weather station located in St Albans, VT [St Albans Radio, VT US]. Monthly precipitation for 2017 was retrieved from [https://www.ncdc.noaa.gov/cdo-

web/datasets/GHCND/stations/GHCND:US1VTFR0019/detail] a weather station in Swanton, VT [Swanton $0.5 \mathrm{NNE}, \mathrm{VT}$ US]. The two stations are located $<10$ miles from each other. Two different stations were selected because neither station provided both the long-term record and the 2017 record.

Annual streamflow records for 2017 from three USGS gauging stations in the Missisquoi watershed and nearby St. Albans Bay were downloaded from the USGS online water information 
portal (https://waterwatch.usgs.gov/index.php?id=ww_current) and plotted in Excel. The three USGS gauging stations are Jewett Brook, station no. 04292810; Mill River, station no. 04292750; and the Missisquoi in Troy, station no. 04293000. Unit area discharges from these three USGS sites were calculated in order to correct for extraneous discharge measurements at Ross Brook. The percent of annual discharge captured within the sampling season was calculated by dividing the discharge in the sampling period by the total annual discharge at all three USGS sites and averaged together. This percentage was then used to calculate prorated annual TP loads for both Ross Brook and Kings Hill Brook.

\section{Limitations}

Some storm events were not captured due to timing, organic matter or baseload clogging the intake tube, and kinks in the tubing. Samples were not collected from the stream at Richford until August due to complications with the ISCO sampler. Predicted monthly loads were not calculated for the Richford stream because all of the $\mathrm{R}^{2}$ values produced by the regressions were too low to make accurate calculations (Figure 7). Predicted loads were not calculated at Ross Brook in October due to leaf interference with the turbidity readings.

\section{Results}

The sampling period, May-October, fell within a relatively wet season (Table 2). Of the six months studied, 2017 rainfall exceeded long-term averages by 0.32 inches to 2.05 inches for all months but September, which had below average rainfall (Table 2). June was the most above average within the sampling period, with 2.05 inches of rainfall above the long-term average recorded throughout the month. Streamflow data from nearby USGS gauging stations (

Figure 2) show that the largest runoff events of 2017 occurred outside the study period, in February and April, with more modestly sized runoff events in June and July and relatively low flow conditions between August and October. 
Table 2. Monthly precipitation for 2017 compared to average precipitation (1981-2010). Precipitation data for 2017 from a station located in Swanton, Vermont. Precipitation not available for January, 2017. Average precipitation collected from a station.

\begin{tabular}{|c|c|c|}
\hline Month & $\begin{array}{c}2017 \\
\text { Precipitation (in) }\end{array}$ & $\begin{array}{c}\text { Average } \\
\text { Precipitation (in) }\end{array}$ \\
\hline January & - & 2.10 \\
\hline February & 2.74 & 1.96 \\
\hline March & 2.97 & 2.65 \\
\hline April & 4.78 & 3.06 \\
\hline May & 4.13 & 3.23 \\
\hline June & 5.78 & 3.73 \\
\hline July & 5.25 & 3.82 \\
\hline August & 4.13 & 3.92 \\
\hline September & 2.51 & 3.58 \\
\hline October & 4.14 & 3.62 \\
\hline November & 2.28 & 3.33 \\
\hline December & 2.10 & 2.68 \\
\hline
\end{tabular}



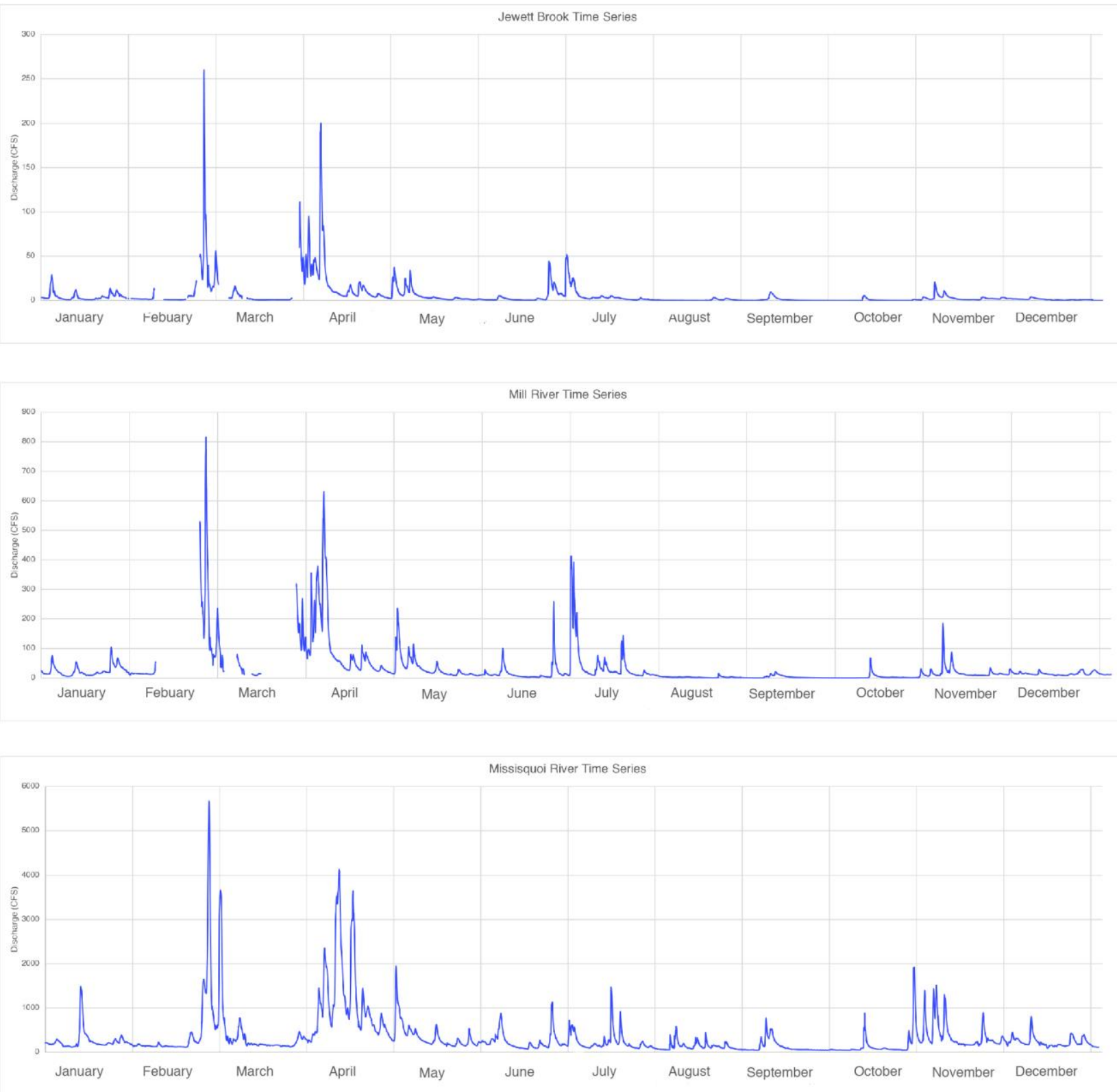

Figure 2. USGS time series for Jewett Brook, station no. 04292810; Mill River, station no. 04292750; and the Missisquoi in Troy, station no. 04293000. Jewett Brook drains a basin of $3.74 \mathrm{mi}^{2}$, Mill River drains a basin of 22.3 $m i^{2}$ and the Missisquoi near North Troy drains a basin of $131 \mathrm{mi}^{2}$.

Stage-discharge relations at all three study sites exhibited non-linear relationships over the range of measurements taken. The logistic model proved to be the best fit for all three sites with $\mathrm{R}^{2}$ values ranging from 0.814-0.982 (Figure 3). Measured stage values over the May through November study period ranged from $0.092 \mathrm{~m}$ to $0.891 \mathrm{~m}$ at Ross Brook, from $0.099 \mathrm{~m}$ to 0.569 $\mathrm{m}$ at Kings Hill Brook, and from $0.129 \mathrm{~m}$ to $0.392 \mathrm{~m}$ at Richford. The equations generated from 
these models were used to calculate discharge every five minutes throughout the entire sampling period.

Kings Hill Brook has the highest predicted maximum discharge and Ross Brook has the lowest (Figure 3). All three sample sites display steep increases in discharge with small increases of stage (Figure 3). Ross Brook appears to increase in discharge between a stage of $1.0-1.75$ feet $(0.31-0.53 \mathrm{~m})$ before beginning to level out at a stage of 2.0 feet $(0.61 \mathrm{~m})$ (Figure 3$)$. Kings Hill Brook has an increase in discharge between a stage of $0.8-1.3$ feet $(0.24-0.40 \mathrm{~m})$ and begins to level off at around a stage of 1.4 feet $(0.42 \mathrm{~m})$ (Figure 3$)$. Richford steadily increases from the lowest recorded level, 0.5 feet $(0.15 \mathrm{~m})$, and begins to level off at a stage of 0.8 feet $(0.24 \mathrm{~m})$ (Figure 3). 

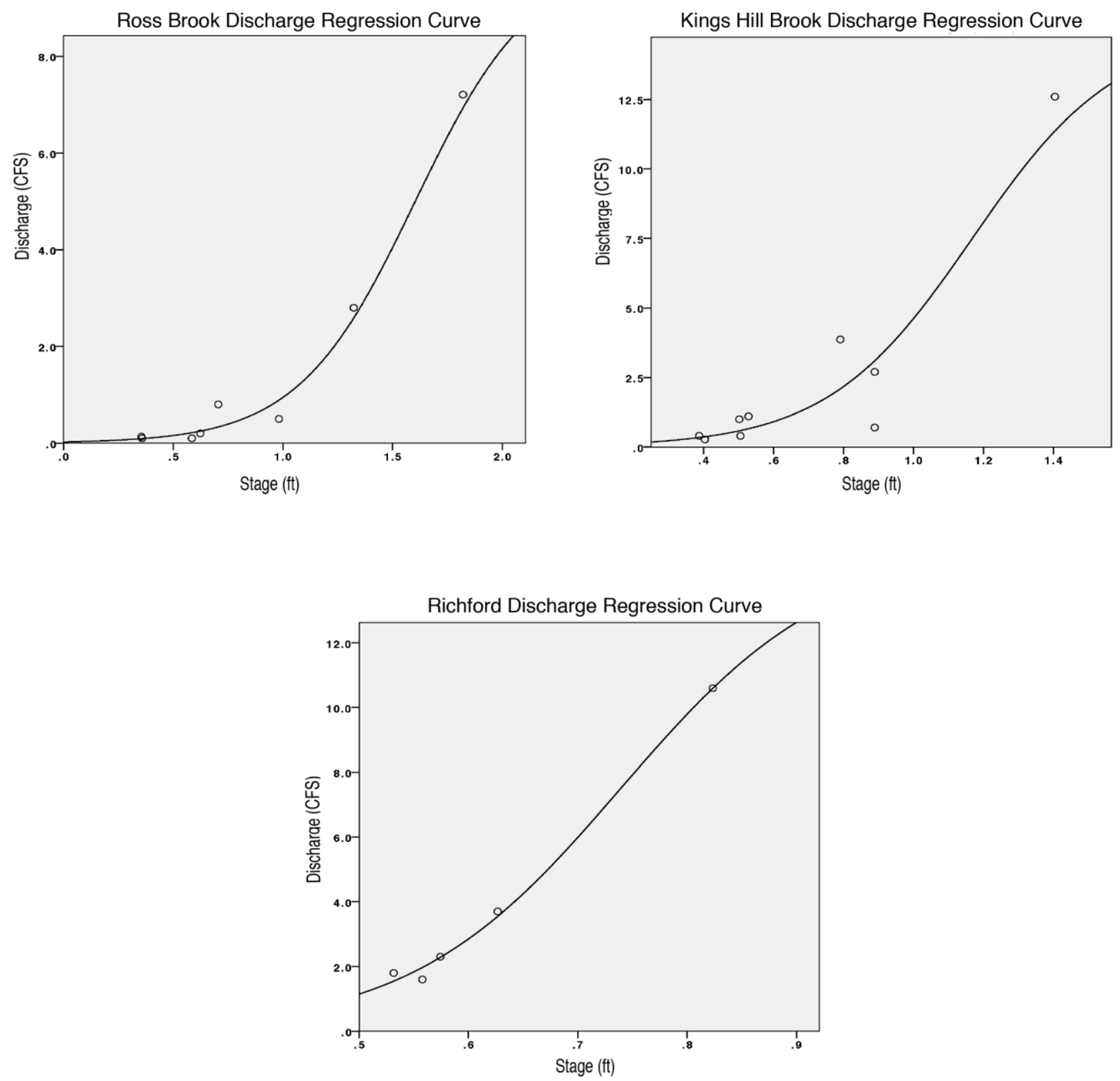

Figure 3. Discharge Rating Curves for Ross Brook, Kings Hill Brook and Richford. The logistic model was used to create all three rating curves.

Ross Brook recorded the lowest discharge of all three sites and one of the highest turbidity readings. (Figure 4). Discharge during precipitation events reached almost 35 CFS and turbidity reached a high of almost 500 NTU (Figure 4). During baseflow periods discharge was typically between 0-3 CFS and turbidity remained between 0-100 NTU, with readings typically closer to 0-10 NTU (Figure 4). During precipitation events discharge values ranged from 1-10 CFS and turbidity readings ranged from $<100$ to 500 NTUs. The turbidity sensor at Ross Brook 
malfunctioned during leaf fall, when the sensor installation was regularly clogged by leaves. For this reason, loads were not calculated for the period of October $1^{\text {st }}, 2017$ to October $31^{\text {st }}, 2017$ at the Ross Brook sample site.

Kings Hill Brook recorded turbidity values between 0-200 NTU and calculated discharge values ranging from 0-15 CFS (Figure 4). During precipitation events discharge ranged from 7-14 CFS and turbidity typically ranged from 100-200 NTU (Figure 4). During baseflow periods discharge was typically between 0-2 CFS and turbidity readings fell within 0-50 NTU, with a couple of readings reaching 100 NTU (Figure 4).

Richford turbidity readings ranged from 0-500 NTU and calculated discharge values fell between 0-15 CFS (Figure 4). During precipitation events turbidity readings typically fell between 0-300 NTU with some events recording turbidity values of 500 NTU. Discharge during storm events typically ranged from 3-15 CFS. During baseflow periods turbidity readings were between 0-100 NTU and discharge ranged from 0-5 CFS (Figure 4). 

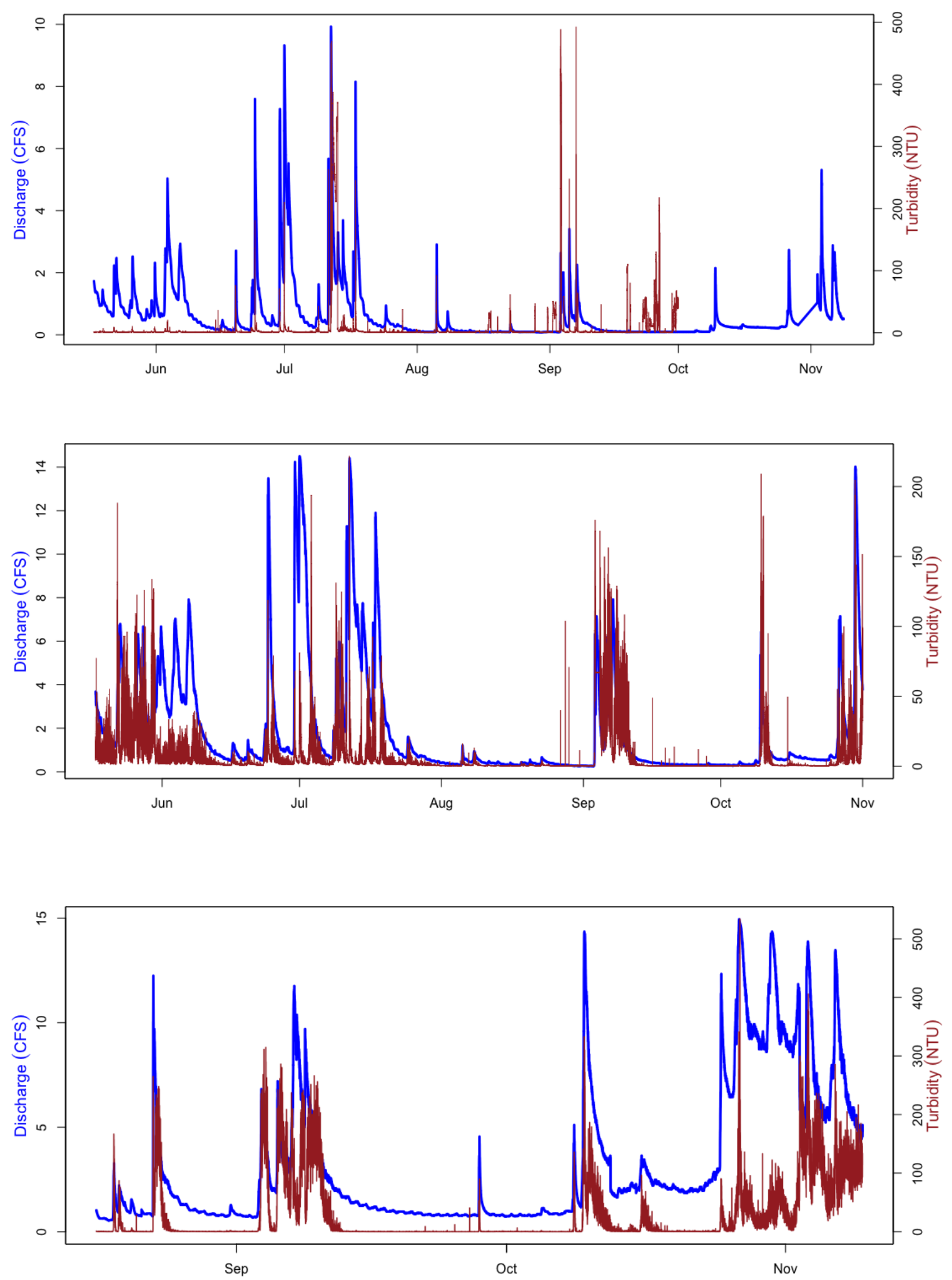

Figure 4. Sampling period discharge and turbidity for Ross Brook (upper), Kings Hill Brook (middle) and Richford (lower) Stream discharge is in blue and turbidity is plotted in red. Note apparent correlations of these two parameters. 
Storm event plots show varying temporal patterns in discharge, turbidity and concentrations for the three study sites (Figure 5). At Ross Brook the concentration data (TP and TSS) appear to closely follow turbidity except during the storm event on July $11^{\text {th }}$ (Figure 5). During this specific storm event both TP and TSS appear to peak during a slight increase in discharge and turbidity, but before either of them reach their maximum (Figure 5). In all three storm events turbidity, TP and TSS all illustrate a relatively "flashy" response to precipitation (Figure 5).

At Kings Hill Brook the relationship between variables is similar, but discharge does not rise and fall as sharply as it tends to in Ross Brook (Figure 5). There is also a greater frequency of rapid fluxes in turbidity. However, overall concentration data appear to closely follow turbidity concentrations. Similarly to Ross Brook, TP, TSS and turbidity show a "flashy" response to precipitation, however at Kings Hill Brook turbidity continues to flux in the falling limb (Figure $5)$.

At the stream at Richford concentration data tend to follow turbidity (Figure 5). This relationship is weaker in the precipitation event on September $8^{\text {th }}$ (Figure 5). Similarly to both Kings Hill Brook and Ross Brook, turbidity, TP and TSS have a "flashy" response in the stream at Richford (Figure 5). Turbidity appears to rise and fall in fluxes that continue through the falling limb, which is also seen at Kings Hill Brook (Figure 5). 

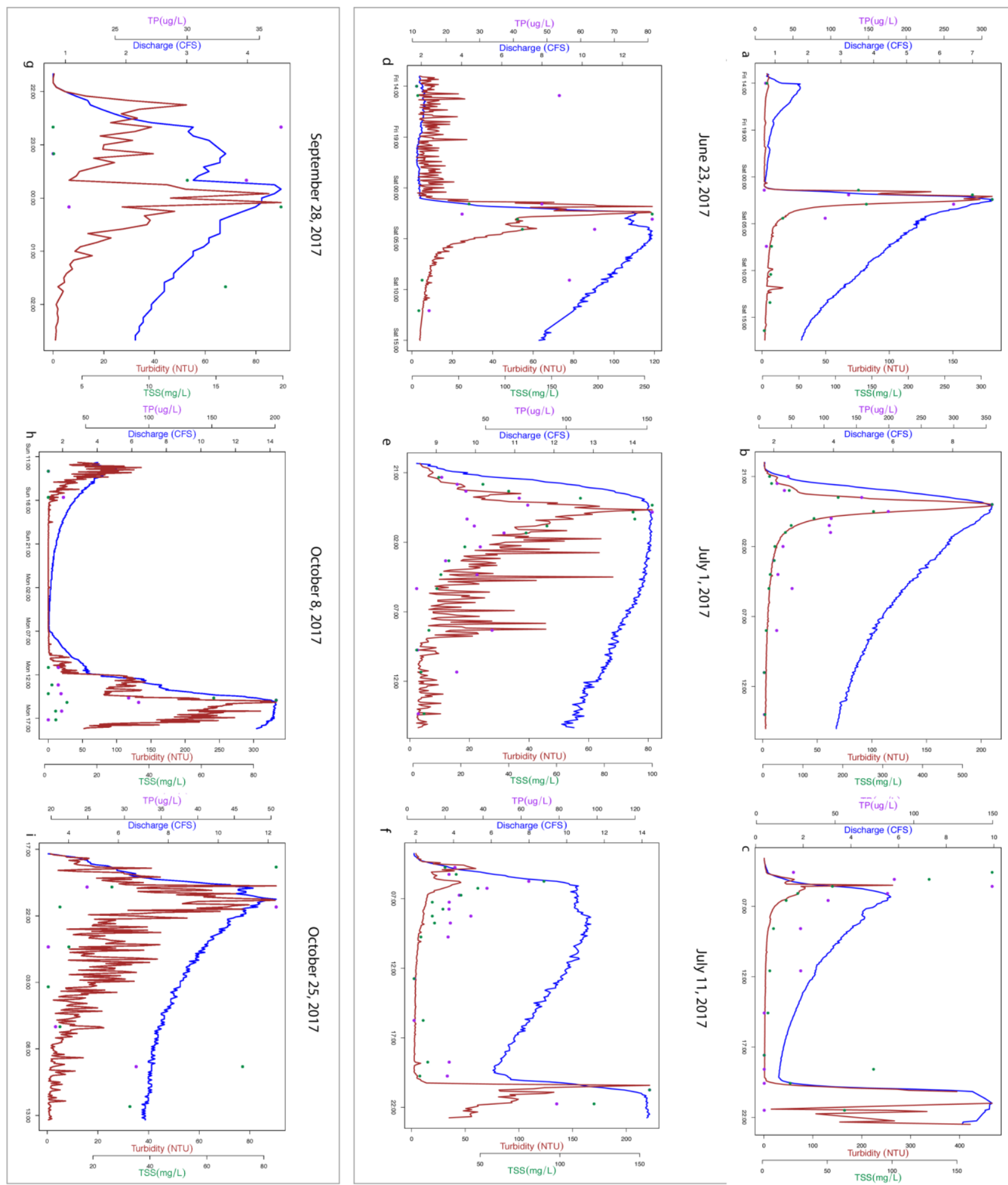

Figure 5(a-i). Individual storm events at Ross Brook (upper panel), Kings Hill Brook (middle panel) and Richford (lower panel). Ross Brook and Kings Hill Brook storm events are from June 23, July 1 and July 11, 2017. Richford storm events are from September 28, October 8 and October 25, 2017. 
SRP at all three sites was quite low. The highest SRP occurred at the beginning of the sampling season, ranging from $\sim 5 \mathrm{ug} / \mathrm{L}$ up to just above $20 \mathrm{ug} / \mathrm{L}$ (Figure 6). However, concentrations were significantly lower throughout the rest of the sampling season, not rising above $\sim 1 \mathrm{ug} / \mathrm{L}$ (Figure 6).

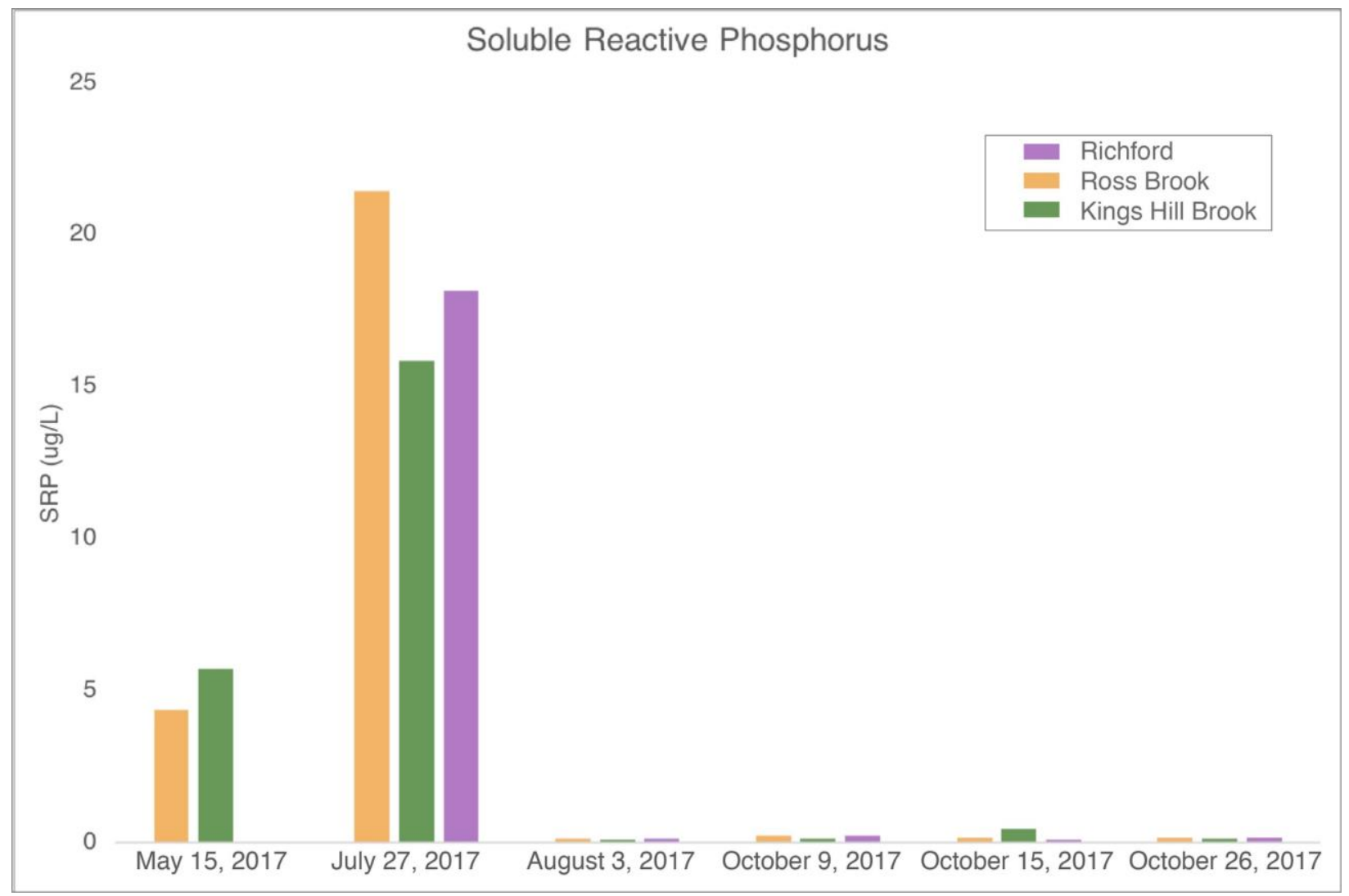

Figure 6. Soluble reactive phosphorus results. Samples were taken periodically throughout the sampling season.

Of the 392 samples collected at the three watersheds and analyzed for TP, 180 fell below the detection limit of $5 \mathrm{ug} / \mathrm{L}$ as measured by the Lachat analyzer. In general, this finding emphasizes the low concentrations of TP commonly found in these streams.

Predictive power of various variables for concentrations of TP and TSS varied among sites (Figure 7). Turbidity proved to be the best predictor for TSS at Ross Brook with an $\mathrm{R}^{2}$ of 0.83 (Figure 7). Turbidity was also the best predictor for TP at Ross Brook with a $\mathrm{R}^{2}$ of 0.77 . At Kings Hill Brook turbidity was the best predictor for TSS with an $\mathrm{R}^{2}$ of 0.69 (Figure 7). The best 
predictor for TP at Kings Hill Brook, however was TSS, with an $\mathrm{R}^{2}$ of 0.64 compared to the $\mathrm{R}^{2}$ of turbidity as a predictor for TP at Kings Hill Brook, which was 0.54 (Figure 7). At Richford all $\mathrm{R}^{2}$ values were below 0.30 (Figure 7) and therefore neither turbidity nor discharge were used to predict TSS and TP concentrations.
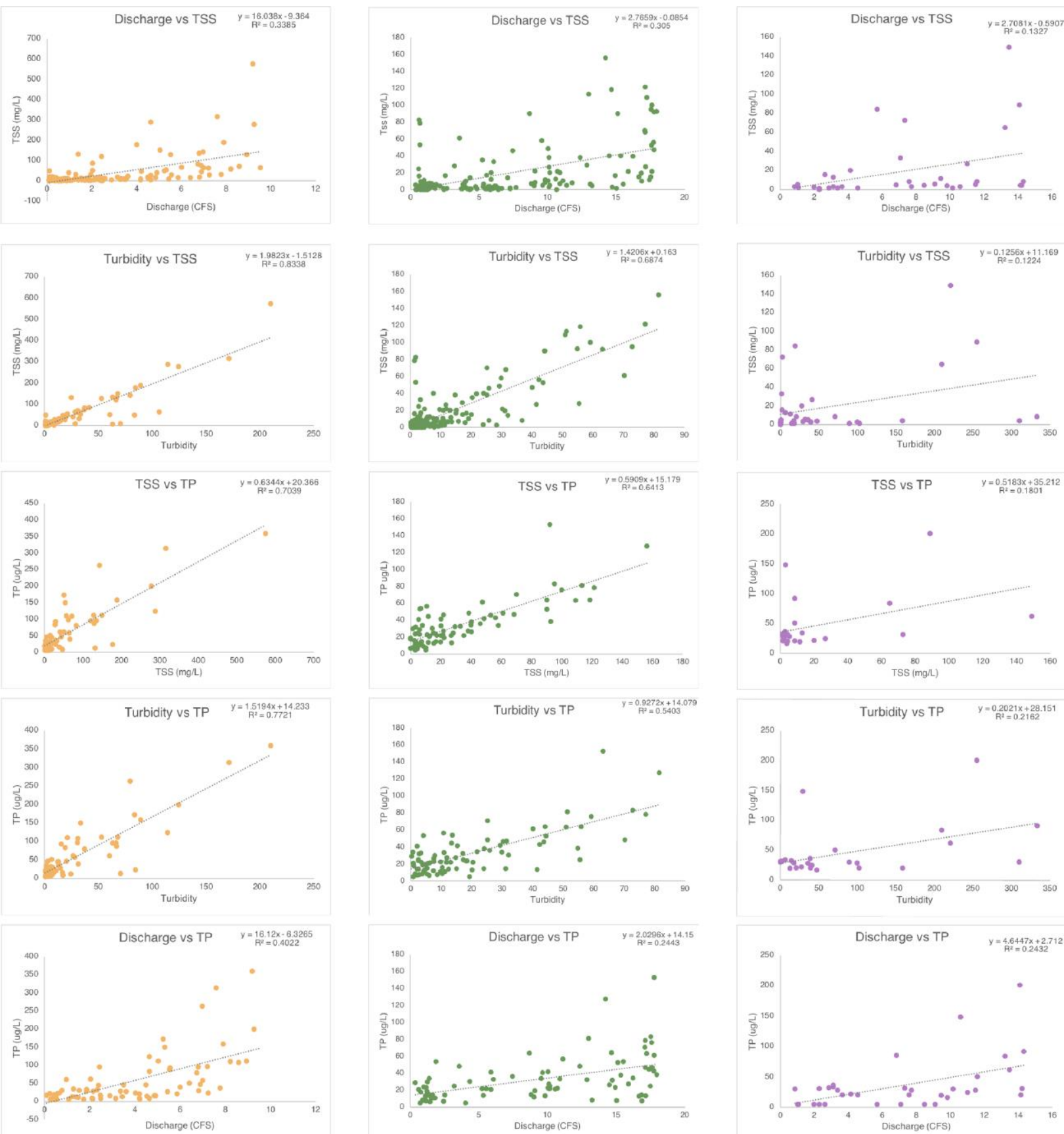

Figure 7. Regressions to determine best predictor for TP and TSS concentrations in Ross Brook (left column), Kings Hill Brook (middle column) and Richford (right column). 
Calculated loads of sediment and TP showed varying patterns in Ross Brook and Kings Hill Brook (Figure 8). Ross Brook had a higher predicted sediment yield in June and July but Kings Hill Brook was predicted to release and carry more sediment in every other month during the sampling period. Ross Brook yielded more P during the months of June and July, whereas Kings Hill Brook yielded more in May, August and September (Figure 8). Monthly loads were not calculated for Ross Brook in October due to interference with the turbidity sensor throughout the month (Figure 8), therefore it is unclear which site is predicted to release more sediment or phosphorus, however Kings Hill Brook released very little P in October compared to the other monthly loads (Figure 8).

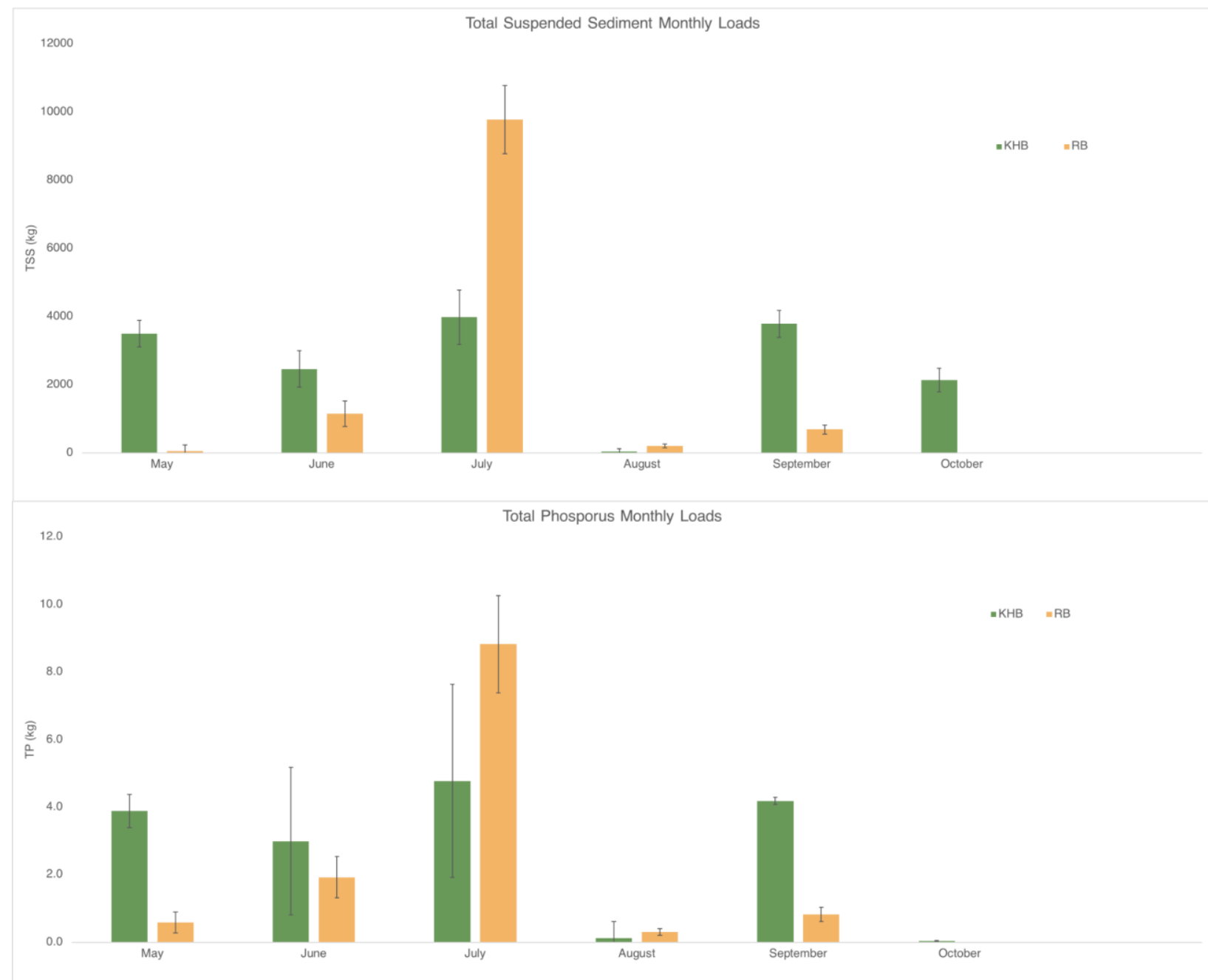

Figure 8. Predicted monthly TSS (kg) and TP (kg) loads from Ross Brook and Kings Hill Brook. Error bars incorporate 95\% confidence intervals on prediction of TSS and TP for each five minute monitoring time step, subsequently multiplied by water volume to estimate load, summed over the month. 
The seasonal predicted P load at Ross Brook is $12.47 \mathrm{~kg}$ and at Kings Hill Brook it is $16.00 \mathrm{~kg}$ (Table 3). For both sites predicted annual loads (kg/ha/yr) are low, $<1 \mathrm{~kg} / \mathrm{ha} / \mathrm{yr}$ of P (Table 3 ). Ross Brook is predicted to export more P annually by area than Kings Hill Brook by an order of magnitude (Table 3).

Table 3. Calculated seasonal loads, unit area seasonal loads and prorated annual load estimates for Ross Brook and Kings Hill Brook.

\begin{tabular}{|c|c|c|c|c|c|}
\hline Sample Site & $\begin{array}{c}\text { Seasonal Load } \\
2017^{1} \\
(\mathrm{~kg})\end{array}$ & $\begin{array}{c}\text { Record length } \\
\text { for load } \\
\text { estimation } \\
\text { (no. months) }\end{array}$ & $\begin{array}{c}\text { Unit area } \\
\text { seasonal load } \\
(\mathrm{kg} / \mathrm{ha})\end{array}$ & $\begin{array}{c}\text { Sampling season } \\
\text { percent of annual } \\
\text { discharge }\end{array}$ & $\begin{array}{c}\text { Prorated } \\
\text { annual load } \\
\text { estimate } \\
(\mathrm{kg} / \mathrm{ha} / \mathrm{yr})\end{array}$ \\
\hline $\begin{array}{c}\text { Ross Brook } \\
(2900 \mathrm{ha})\end{array}$ & 12.47 & 5 & 0.004 & 0.26 & 0.02 \\
\hline $\begin{array}{c}\text { Kings Hill Brook } \\
(8500 \mathrm{ha})\end{array}$ & 16.00 & 6 & 0.002 & 0.27 & 0.01 \\
\hline
\end{tabular}

1. Sum of the monthly loads presented in Figure 8

${ }^{2}$ Prorated by dividing unit area seasonal load by sampling season percent of annual discharge. Assumes load for record length is representative of annual load.

Calculated predicted loads of annual P export $(\mathrm{kg} / \mathrm{ha})$ fall within the margins of the SWAT model (Figure 9). For both Ross Brook and Kings Hill Brook, calculated predicted P exports are on the lower end of the predictions generated by the model (Figure 9). The model illustrates variability within the two watersheds of $\mathrm{P}$ sources and predicted $\mathrm{P}$ export. Within Ross Brook predicted P export ranges from 0-4.1 kg/ha and within Kings Hill Brook predicted P exports range from $0-1.87 \mathrm{~kg} /$ ha with one area at the boundary of the watershed predicting exports of up to $7.86 \mathrm{~kg} /$ ha (Figure 9). The model also showed that roads are predicted to export between 0.63 $1.87 \mathrm{~kg} /$ ha of $\mathrm{P}$ annually (Figure 9). 

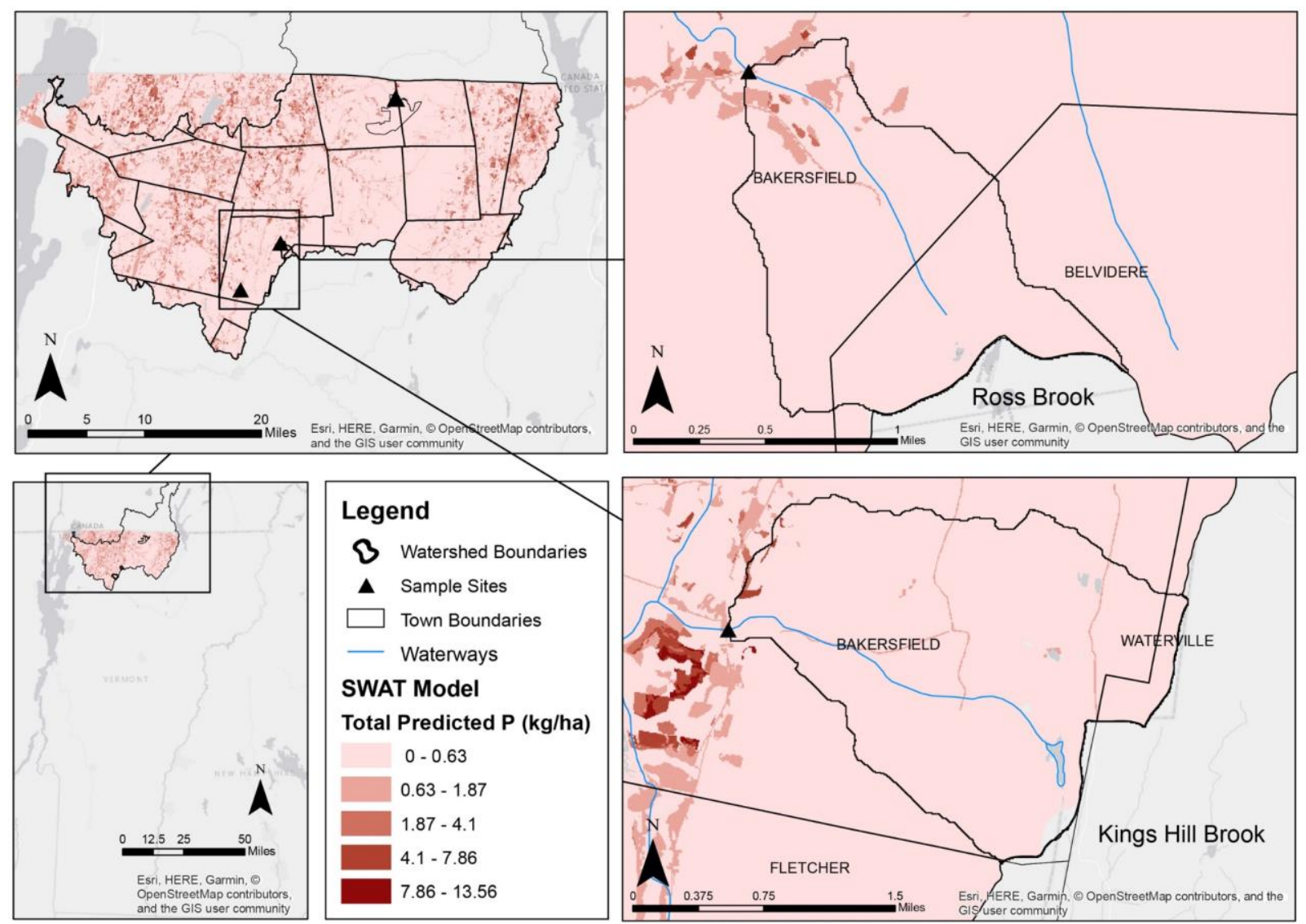

Figure 9. Sample sites in context of Vermont and the Missisquoi Basin. SWAT model (Winchell et al., 2015) results illustrate predicted annual P export (kg/ha) for Ross Brook (upper right) and Kings Hill Brook (lower right).

\section{Discussion}

This study found that the forested watersheds studied exported very low concentrations of $\mathrm{P}$ and TSS. This suggests that naturally occurring P concentrations in forested areas are also low. Both calculated loads and loads extrapolated from the SWAT model (Winchell et al., 2015) predict that forested watershed will export less than $1 \mathrm{~kg} / \mathrm{ha} / \mathrm{yr}$ of P. Given how minimal the analyzed concentrations of $\mathrm{P}$ and predicted $\mathrm{P}$ exports are, significantly reducing these loads could prove to be difficult.

This research illustrates that forested watersheds are highly responsive to precipitation events.

Given that the watersheds included in this study are managed for logging and maple sugaring, 
the use of trails or dirt roads associated with these practices could introduce some sediment and nutrients, however not to the same degree as precipitation events. In the time series' (Figure 4) for all three sites it is clear that turbidity rises with discharge and remains relatively constant throughout periods of baseflow. Due to the composition of these watersheds, there is little disturbance aside from precipitation that would result in the transport of sediment and nutrients into nearby streams.

Furthermore, it is likely that the sources of sediment are located in close proximity to the streams. Based off the individual storm event plots (Figure 5) it is clear that turbidity, TSS and TP all demonstrate a "flashy" response to precipitation, whereas discharge has a more gradual falling limb, illustrating hysteresis. The rapid rise and fall of turbidity, TSS and TP suggest that the source of sediment is located near the stream, allowing sediment concentrations to increase with the rising limb of discharge, but that the source is limited or easily exhausted, which would explain the rapid decrease in sediment concentration while discharge decreases more gradually. The exact sources of sediment and nutrients within these specific landscapes are unknown. However, it is likely that the exposed trail and gravel road surfaces in these watersheds contribute to the overall sediment and nutrient concentrations (EPA, 2016b). Given that the sediment source is likely located near the stream, it is possible that gravel roads crossing the stream or other nearby trails and dirt roads release sediment that is quickly transported into the stream. Additional proximal sources of sediment include the streambank and adjacent riparian zones that run alongside the streams (EPA, 2016b). Due to the inherent stability of forested soils (Cardoso et al., 2013) it is possible that the sediment released into the streams during precipitation events is a result of natural weathering and the limited supply of sediment released can be explained by the stability of these soils and riparian zones.

Several sources of uncertainty associated with this study should be acknowledged. The loads estimated through this study include a degree of uncertainty generated through the use of confidence intervals associated with the prediction equations show in Figure 7. Beyond this source of uncertainty, uncertainty associated with the rating equations used to convert water level to discharge have not been quantified. Error in the discharge measurements or application of the rating equations to water levels above field-measured values would add additional uncertainty 
into the estimates provided here. In addition, this study was conducted only between May November in 2017. Concentrations of sediment and P in spring snowmelt flows have not been measured, and extrapolation of the seasonal results to the entire year provided in Table 3 do not account for this source of uncertainty.

\section{Implications}

The results of this study suggest that predicted annual total $\mathrm{P}$ exports from forested watersheds fall within the lowest predicted range produced by the SWAT model. This indicates that most P export is likely a product of natural processes, including erosion and potentially a smaller source could be found in groundwater upwelling (Kelley et al., 1999; Filipelli, 2008). As a result, reducing $\mathrm{P}$ export from forested watersheds by $50 \%$, as mandated in the EPA reduction plans (EPA, 2016a), may prove difficult considering how low the predicted annual exports are.

The sampling season was wetter than normal (Table 2), suggesting that more sediment and $\mathrm{P}$ were released than in the average season. The predicted effects of climate change on Vermont include an increase in precipitation events (VCA, 2018). As mentioned above, this study illustrates that precipitation is one of the main drivers of sediment and nutrient export from forested areas. Therefore given the predicted increase in precipitation, it is likely that more $\mathrm{P}$ and sediment will be exported in the coming seasons.

\section{Management}

The recommended management plans stated in the EPA report address reducing streambank erosion and increasing floodplain protection (EPA, 2016a). Both of these suggestions have the potential to reduce the quantity of sediment entering the waterway and therefore decrease the amount of $\mathrm{P}$ export as well. Increasing the stability of stream banks and resiliency of floodplains has the potential to reduce $P$ inputs into streams, especially at Ross Brook due to the erodibility of the stream bank and low-lying vegetation in the floodplain. Increasing floodplain resiliency would also likely prove beneficial at Kings Hill Brook because there is a gap between the rocky stream bank plain and dense forest cover. Addressing this area and stabilizing the plain could reduce additional sediment and $\mathrm{P}$ inputs during events that reach flood stage. 
Another management practice that could reduce $\mathrm{P}$ inputs in forested landscapes is the reduction of erosion from forested and dirt roads (EPA, 2016b). At both watersheds there are exposed surfaces in the form of gravel roads and trail networks. At Kings Hill Brook there is a dirt road that runs along the top of the slope and eventually crosses upstream. This road releases sediment and nutrients into the stream. Introducing vegetation alongside the road and reducing the impacts of the road crossing the stream could reduce sediment and $\mathrm{P}$ export during precipitations events. At Ross Brook there is a trail network which is a part of the Vermont Association of Snow Travelers (VAST). These trails are accessible year-round and have the potential to release sediment into the stream. Ensuring that there are stable buffers between these trails and the stream could reduce both sediment and nutrient inputs into the steam.

\section{Future Work}

Given that samples were collected from May-November, it is unknown how these watersheds respond during winter months. The ISCO samplers were deployed after spring melt and therefore the quantity of sediment and $\mathrm{P}$ released during this part of the year remains undetermined. Future work on this project could include deploying ISCO samplers either year round or before spring melt in order to account for sediment and nutrients entering the system during periods of melt. Including these contributions to the annual loads could prove beneficial in gaining a better overall understanding of the dynamics of sediment and $\mathrm{P}$ in forested watersheds.

Focused analysis on soil $\mathrm{P}$ fluxes could also aid in gaining a more comprehensive understanding of the processes at play contributing to $\mathrm{P}$ export in forested areas. Installing ISCO samplers above and below road crossings could help to quantify the contribution of these roads to overall sediment and nutrients concentrations in the streams. Furthermore, understanding the quantity of sediment that is introduced from roads could play a role in successfully developing management plans.

Additional analysis of the role of soluble reactive P (SRP) in forested systems could also prove beneficial. In this study SRP appeared to be highest in July, with concentrations near $20 \mathrm{ug} / \mathrm{L}$ and then dropped below detection limit later in the sampling season (Figure 6). SRP is directly taken up by plants, whereas TP is a more general measure of all forms of $\mathrm{P}$ present in the system 
(Murphy, 2007). Therefore, analyzing samples for SRP in addition to TP could provide a better image of the dynamics at play with $\mathrm{P}$ and what percent of $\mathrm{P}$ is readily accessible to plants.

\section{Conclusions}

Forested watersheds are highly responsive to precipitation events in terms of sediment and nutrient input into waterways. This study illustrates that in these watersheds sources of sediment are located near waterways and are limited in immediate supply. Given the management of the forested watersheds studied, dirt roads and trails could be important sources of sediment and P, in addition to stable streambanks and riparian zones. Phosphorus export from streams draining forested watersheds is connected to total suspended sediment. Best management practices, including slope stabilization and increasing flood plain resiliency could prove beneficial in reducing $\mathrm{P}$ export from forested catchments. However, the predicted annual export of $\mathrm{P}$ is very low, less than $1 \mathrm{~kg} / \mathrm{ha} / \mathrm{yr}$, suggesting that reducing this export by $50 \%$ may prove difficult. 


\section{References}

Abrams, M. M., and W. M. Jarrell. 1995. Soil-Phosphorus as a Potential Nonpoint-Source for Elevated Stream Phosphorus Levels. Journal of Environmental Quality 24 (1):132-138.

Allan, J. D., Erickson, D. L., Fay, J. 1997. The influence of catchment land use on stream integrity across multiple spatial scales. Freshwater Biology 37:149-161.

Alvarez, X., E. Valero, R. M. B. Santos, S. G. P. Varandas, L. F. S. Fernandes, and F. A. L. Pacheco. 2017. Anthropogenic nutrients and eutrophication in multiple land use watersheds: Best management practices and policies for the protection of water resources. Land Use Policy 69:111.

American Public Health Association, A. W. W. A., and Water Pollution Control Federation. 1998. Standard methods for the examination of water and wastewater 20th ed.

Anderson, B., and D. E. Potts. 1987. Suspended sediment and turbidity following road construction and logging in western Montana. Water Resources Bulletin 23 (4):681-690.

Bennett, E. M., S. R. Carpenter, and N. F. Caraco. 2001. Human impact on erodible phosphorus and eutrophication: A global perspective. BioScience 51 (3):227-234.

Beschta, R. L. 1979. Debris removal and its effects on sedimentation in an Oregon coastal range stream. Northwest Science 53:71-77.

Bilby, R. E. 1985. Contributions of Road Surface Sediment to a Western Washington Stream. Forest Science 31 (4):827-838.

Binkley, D., G. G. Ice, J. Kaye, and C. A. Williams. 2004. Nitrogen and phosphorus. Journal of the American Water Resources Association:1277-1291.

Cardoso, E. J. B. N., R. L. F. Vasconcellos, D. Bini, M. Y. H. Miyauchi, C. Alcantara dos Santos, P. R. L. Alves, A. Montiero de Paula, A. S. Nakatani, J. Moraes Pereira, and M. A. Nogueira. 2013. Soil health: looking for suitable indicators. What should be considered to assess the effects of use and management on soil health? Scientia Agricola 70 (4):274-289.

Carpenter, S. R., N. F. Caraco, D. L. Correll, R. W. Howarth, A. N. Sharpley, and V. H. Smith. 1998. Nonpoint pollution of surface waters with phosphorus and nitrogen. Ecological Applications 8 (3):559-568.

Christie, T., and W. K. Fletcher. 1999. Contamination from forestry activities: implications for stream sediment exploration programs. Journal of Geochemical Exploration 67 (1-3):201-210.

Collins, A. L., and D. E. Walling. 2004. Documenting catchment suspended sediment sources: problems, approaches and prospects. Progress in Physical Geography 28 (2):159-196.

Committee, L. C. 2018. Cyanobacteria in Lake Champlain 2017 [cited March 22 2018].

Cooke, S. E., and E. E. Prepas. 1998. Stream phosphorus and nitrogen export from agricultural and forested watersheds on the Boreal Plain. Canadian Journal of Fisheries and Aquatic Sciences 55 (10):2292-2299.

Delmas, M., N. Saby, D. Arrouays, R. Dupas, B. Lemercier, S. Pellerin, and C. Gascuel-Odoux. 2015. Explaining and mapping total phosphorus content in French topsoils. Soil Use and Management 31 (2):259-269.

DeWolfe, M. N., Hession, W.C., and Watzin, M.C. . 2004. Sediment and phosphorus loads from streambank erosion in Vermont, USA. Critical Transitions in Water and Environmental Resources Management.

Elliot, W. J., Dumroese, D. P., Robichaus, P. R. 1999. The Effect of Forest Management on Erosion and Soil Productivity. In Soil Quality and Soil Erosion, ed. R. Lal: Soil and Water Conservation Society. 
EPA. 2016a. Phosphorus TMDLs for Vermont Segments of Lake Champlain. Boston, MA: U.S. Environmental Protection Agency.

EPA. 2016b. Nonpoint Source: Forestry 2016 [cited March 28 2017].

EPA. 2016c. What is Sediment Pollution? Kansas City, Missouri: Mid-America Regional Council.

EPA. 2016d. Definition and Procedure for the Determination of the Method Detection Limit, Revision 2, ed. O. o. Water, 1-8. Washington, DC: EPA.

Filippelli, G. M. 2008. The global phosphorus cycle: Past, present, and future. Elements 4 (2):89-95.

Gaddis, E. J. B. V., A. 2009. Spatially Explicit Modeling of Land Use Specific Phosphorus Transport Pathways to Improve TMDL Load Estimates and Implementation Planning. Water Resources Management 24 (8):1621-1644.

General Assembly of the State of Vermont. 2015. An act relating to improving the quality of State waters. In 64, ed. V. T. Legislature. Montpelier, VT.

Ghebremichael, L. T., T. L. Veith, and M. C. Watzin. 2010. Determination of Critical Source Areas for Phosphorus Loss: Lake Champlain Basin, Vermont. Transactions of the ASABE 53 (5):15951604.

Ghebremichael, L. T., and M. C. Watzin. 2011. Identifying and controlling critical sources of farm phosphorus imbalances for Vermont dairy farms. Agricultural Systems 104 (7):551-561.

Gomi, T., Moore, R. D., Hassan, M. A. 2005. Suspended sediment dynamics in small forested streams on the Pacific Northwest. Journal of the American Water Resources Association:877-897.

Grundtner, A., S. Gupta, and P. Bloom. 2014. River bank materials as a source and as carriers of phosphorus to lake pepin. J Environ Qual 43 (6):1991-2001.

Gu, S., G. Gruau, R. Dupas, C. Rumpel, A. Creme, O. Fovet, C. Gascuel-Odoux, L. Jeanneau, G. Humbert, and P. Petitjean. 2017. Release of dissolved phosphorus from riparian wetlands: Evidence for complex interactions among hydroclimate variability, topography and soil properties. Sci Total Environ 598:421-431.

Harr, R. D. 1977. Water flux in soil and subsoil on a steep forested slope. Journal of Hydrology 33:3758.

Jackson, W. L., and R. L. Beschta. 1982. A model of two-phase bedload transport in an Oregon coast range stream. Earth Surface Processes and Landforms 7:517-527.

Johnes, P. J. 1996. Evaluation and management of the impact of land use change on the nitrogen and phosphorus load delivered to surface waters: The export coefficient modelling approach. Journal of Hydrology 183 (3-4):323-349.

Joung, D., M. Leduc, B. Ramcharitar, Y. Y. Xu, P. D. F. Isles, J. D. Stockwell, G. K. Druschel, T. Manley, and A. W. Schroth. 2017. Winter weather and lake-watershed physical configuration drive phosphorus, iron, and manganese dynamics in water and sediment of ice-covered lakes. Limnology and Oceanography 62 (4):1620-1635.

Kelly, V. J., D. D. Lynch, and S. A. Rounds. 1999. Sources and transport of phosphorus and nitrogen during low-flow conditions in the Tualatin River, Oregon, 1991-91. In USGS Water-Supply Paper 2465-C. Reston, Virginia: United States Geological Survey.

Kreutweiser, D. P., and S. S. Capell. 2001. Fine sediment deposition in streams after selective forest harvesting without riparian buffers. Canadian Journal of Forest Research 31:2134-2142.

Kronvang, B., J. Audet, A. Baattrup-Pedersen, H. S. Jensen, and S. E. Larsen. 2012. Phosphorus load to surface water from bank erosion in a Danish lowland river basin. J Environ Qual 41 (2):304-13.

Kurashige, T. 1994. Mechanisms of suspended sediment supply to headwater rivers. Transaction of Japanese Geomorphological Union 15 (A):109-129. 
Lee, G. F., Jones, R. A., Lang, L. E. 1985. Development of a Phosphorus-Eutrophication Management Strategy for Vermont: Evaluating Available Phosphorus Loads. Construction Engineering Research Laboratory.

Leighton, M. O. 1905. Prelimiary Report on the Pollution of Lake Champlain. In Quality of Water, ed. C. D. Walcott. Washington, D.C.: Department of The Interior.

Liu, Y., G. Villalba, R. U. Ayres, and H. Schroder. 2008. Global phosphorus flows and environmental impacts from a consumption perspective. Journal of Industrial Ecology 12 (2):229-247.

Luce, C. H., and T. A. Black. 1999. Sediment production from forest roads in western Oregon. Water Resources Research 35 (8):2561-2570.

Luce, C. H., and B. C. Wemple. 2001. Introduction to special issues on hydrologic and geomorphic effects of forest roads. Earth Surface Processes and Landforms 26:111-113.

Meals, D. W. 1996. Watershed-scale response to agricultural diffuse pollution control programs in Vermont, USA. Water Science and Technology 33 (4-5):197-204.

Meyer, J. L., and G. E. Likens. 1979. Transport and transformation of phosphorus in a forest stream ecosystem. Ecology 60 (6):1255-1269.

Murphy, S. 2007. General Information on Phosphorus. In Water Quality Monitoring: USGS.

Odhiambo, B. K., M. C. Ricker, L. M. Le Blanc, and K. A. Moxey. 2016. Effects of forested floodplain soil properties on phosphorus concentrations in two Chesapeake Bay sub-watersheds, Virginia, USA. Environ Sci Pollut Res Int 23 (16):16056-66.

Ostrofsky, M. L., A. G. Stolarski, and K. A. Dagen. 2018. Export of Total, Particulate, and Apatite Phosphorus from Forested and Agricultural Watersheds. J Environ Qual 47 (1):106-112.

Pilotto, L. S., R. M. Douglas, M. D. Burch, S. Cameron, M. Beers, G. J. Rouch, P. Robinson, M. Kirk, C. T. Cowie, S. Hardiman, C. Moore, and R. G. Attewell. 1997. Health effects of exposure to cyanobacteria (blue-green algae) during recreational water-related activities. Aust NZJ Public Health 21 (6):562-6.

Program, L. C. B. Cyanobacteria (Blue-Green Algae) 2017 [cited 3/22/2018.

Reid, L. M., and T. Dunne. 1984. Sediment production from forest road services. Water Resources Reseach 20:1753-1761.

Rivenbark, B. L., and C. R. Jackson. 2004. Concentrated flow breakthroughs moving through silvicultural streamside management zones: Southeastern Piedmont, USA. Journal of the American Water Resources Association 40 (4):1043-1052.

Sheridan, G. J., and P. J. Noske. 2007. Catchment-scale contribution of forest roads to stream exports of sediment, phosphorus and nitrogen. Hydrological Processes 21 (23):3107-3122.

Smeltzer, E., Walker, W. W., Garrison, V. . 1989. Eleven Years of Lake Eutrophication Monitoring in Vermont: A Critical Evaluation Enhancing States' Lake Management Programs:53-62.

Smeltzer, E. 1999. Phosphorus Management in Lake Champlain. American Geophysical Union:435-451.

USGS. 2017. The effects of urbanization on water quality:Erosion and sedimentation 2016 [cited March 28 2017].

Van Dolah, F. M. 2000. Marine algal toxins: origins, health effects, and their increased occurrence. Environmental Health Prospects 108 (1):133-141.

Vermont Climate Assessment (VCA). 2018. VT's Changing Climate. [cited April 22nd, 2018.

Walling, D. E. 1983. The Sediment Delivery Problem. Journal of Hydrology 65 (1-3):209-237.

Walling, D. E. 1999. Linking land use, erosion and sediment yields in river basins. Hydrobiologia 410:223-240. 
Walsh, C. J., T. D. Fletcher, and A. R. Ladson. 2005. Stream restoration in urban catchments through redesigning stormwater systems: looking to the catchment to save the stream. Journal of the North American Benthological Society 24 (3):690-705.

Wang, D., Dorioz, J-M., Trevisan, D., Braun, D.C., Windhausen, L.J., and Vansteelant, J-Y. 2004. Using a landscape approach to interpret diffuse phosphorus pollution and assist with water quality management in the basins of Lake Champlain (Vermont) and Lac Léman (France). Lake Champlain: Partnerships and Research in the New Millennium:159-190.

Wemple, B. C., F. J. Swanson, and J. A. Jones. 2001. Forest roads and geomorphic process interactions, Cascade Range, Oregon. Earth Surface Processes and Landforms 26 (2):191-204.

WHO. 1990. Toxic Cyanobacteria in Water: A guide to their public health consequences, monitoring and management. Bury St Edmunds, Great Britain: St Edmundsbury Press.

Winchell, M. F., S. Folle, D. Meals, J. Moore, R. Srinivasan, and E. A. Howe. 2015. Using SWAT for sub-field identification of phosphorus critical source areas in a saturation excess runoff region. Hydrological Sciences Journal-Journal Des Sciences Hydrologiques 60 (5):844-862.

Xu, F., Tao, S., Dawson, R. W., Li, P. and CAO, J. 2001. Lake Ecosystem Health Assessment: Indicators and Methods. Water Research 35 (13):3157-3167.

Young, E. O., and D. S. Ross. 2001. Phosphate release from seasonally flooded soils: a laboratory microcosm study. Journal of Environmental Quality 30 (1):91-101.

Young, E. O., D. S. Ross, C. Alves, and T. Villars. 2012. Soil and landscape influences on native riparian phosphorus availability in three Lake Champlain Basin stream corridors. Journal of Soil and Water Conservation 67 (1):1-7.

Yuan, Y., Binger, R. L., Locke, M. A. 2009. A Review of effectiveness of vegetative buffers on sediment trapping in agricultural areas. Ecohydrology 2:321-336.

Ziemer, R. R. 1981. Roots and the stability of forested slopes. IAHS 132:343-361. 
